\title{
CRUSHING OF ROASTED ARABICA COFFEE BEANS
}

\author{
Š. Nedomová
}

Received: March 23, 2010

\begin{abstract}
NEDOMOVÁ, Š.: Crushing of roasted Arabica coffee beans. Acta univ. agric. et silvic. Mendel. Brun., 2010, LVIII, No. 4, pp. 177-182

Paper deals with experimental research on the crushing of coffee beans of different kinds under quasi-static compression. The process of the crushing is described in details. It has been shown that there is variability in the crushing strength values. A relation between crushing strength and the coffee grain shape is also studied. Roasted Arabica coffee (Coffea arabica) beans were used for analyses. Arabica coffees were produced in Colombia and Indonesia. Abbreviation in the square brackets indicates the coffee type and it is used in the text hereinafter. All Arabica samples were submitted to a light roast. The detail analysis of the experimental data shows that there is no significant relation between parameters describing the fracture behaviour of the grains and grain geometry. These parameters are also independent on the grain weight. Compression of the coffee grains leads to their crushing. The fracture force is different for the different kinds of the coffee. The same is fact valid also for the strain at the fracture and for the energy absorbed during the grain crushing. The obtained results suggest that the fracture parameters obtained at the compression loading are dependent only on the coffee brand and on the roasting conditions.
\end{abstract}

coffee grain, grain shape, breaking force, fracture strain, absorbed energy

The knowledge of the strength and toughness of the coffee beans is necessary in order to evaluate their brittleness. The reaching of a certain degree of brittleness is very important for the grinding to which coffee beans have to be subjected to before brewing. The uniformity of the product of the grinding process depends on various factors including the brittleness of the roasted coffee bean and it affects the extraction of soluble solids to obtain the coffee brew (Clo and Voilley, 1983; Clarke and Macrae, 1985). Even though the changes in the textural and mechanical characteristics to which the coffee bean undergo during roasting play a relevant role in the quality of the roasted beans, these properties have been scarcely studied until now. Considering the possible causes of the relevant change of the texture during roasting, one effect could be attributed to the noticeable reduction of density due to the volume increase and to the corresponding increase of porosity of the bean structure determined by the increase of the pressure of the internal gases, products of the heat-induced re- actions (mainly water vapour and carbon dioxide, but also pyrolysis reaction products) (Massini et al., 1990; Gutierrez et al., 1993). It is known, in fact, that the overall mechanical properties of a food could be related to the cell structure, which is typical for various vegetables, and fruits or they may result from the physical state, or porosity (Roos, 1995). On the other hand, one of the main factors that may significantly affect mechanical properties of foods during processing and storage is the presence of plasticizers, where water can be considered the most important (Roos, 1995). Some authors discovered the effect of moisture content and water activity on selected mechanical properties, such as the hardness, toughness and breaking force of cereals, intact legumes and nuts (Tran et al., 1981; Saleh and Gallant, 1985; Borges and Peleg, 1997).

In order to study the effects mentioned above the process of the coffee grain crushing must be studied. There is an only little works on this topic see e.g. Pittia et al. (2001). The submitted paper is fo- 
cused on the detail description of the crushing behaviour of the coffee grains under compression.

\section{MATERIALS AND METHODS}

\section{Coffee samples}

Roasted Arabica coffee (Coffea arabica) beans were used for analyses. Arabica coffees were produced in Colombia [C1, C2, C3], and Indonesia [I1, I2]. Abbreviation in the square brackets indicates the coffee type and it is used in the text hereinafter. All Arabica samples were submitted to a light roast. The beans were ordered from commercial distribution network in the Czech Republic. All analyses were performed for samples of 20 beans randomly selected from each lot. Samples details are listed in Table I.

\section{Quantitative measurement of the coffee bean dimensions}

Dimensions in the main axes (D1, D4, D7 see Fig. 1) were measured using a digital calliper SOMET (Germany). With regard to measurement accuracy and relevance, one decimal number was considered. According to indication by other authors (Ghosh and Gacanja, 1970) D1, D4, and D7 dimensions correspond to $W$ (width), $D$ (depth) and $L$ (length), respectively. Remaining dimensions (D2, D3, D5, D6 - see Fig. 1) were determined from digital images using Corel DRAW X3 (Corel Corporation, USA). The knowledge of the grain size and namely its shape may be very important. As it was shown e.g. the shape of agricultural products can significantly affects their mechanical properties (Nedomová et al., 2009).

\section{Mechanical Testing}

A TIRA Universal Testing Machine, equipped with a $200 \mathrm{~N}$ load cell was used. For the measurements, 20 beans of each sample were taken at random, and then positioned individually on its longest side and with the flat side up between two metal parallel plates of the dynamometer. Compression force was applied at a rate of $20 \mathrm{~mm} / \mathrm{min}$ until failure occurred; working temperature was $25^{\circ} \mathrm{C}$. Owing to the difficulty to calculate the true stress and strain, the mechanical properties of the coffee beans were characterized with the following empirical measurements carried out in the force-displacement curve (Borges and Peleg, 1997):

- Breaking force $(\mathrm{N})$ corresponding to force at the major failure event. It was considered as empirical measure of the crushing strength;

- Strain at fracture (\%) corresponding to the deformation at the first breaking point and used as index of the deformability; it was expressed as percentage to keep into account the actual dimensions of the differently heat treated beans;

- Work (J) corresponding to the area under the force - displacement curve until the first breaking event occurred. This parameter has been used as empirical index of toughness. This work represents an absorbed energy during the grain crushing.

Twenty grains have been tested for every coffee type.

\section{Front view}

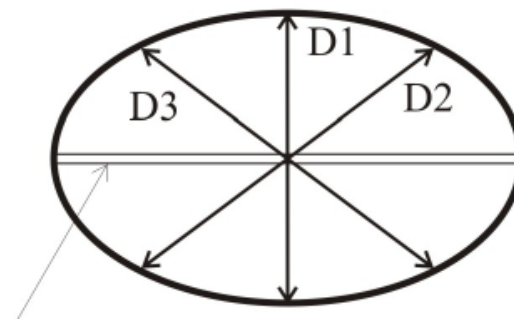

Joint

1: Illustration of measuring sides for coffee beans
Top view

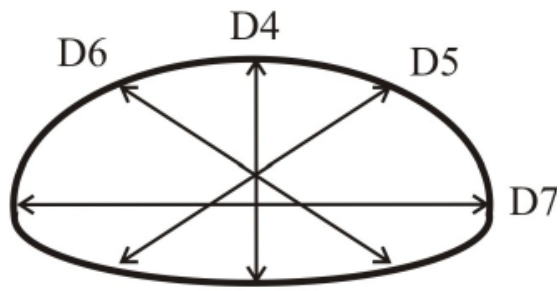

I: Selected physical characteristics of different coffee brands

\begin{tabular}{lccccc}
\hline \multicolumn{1}{c}{ Coffee code } & Coffee brand & $\begin{array}{c}\text { Mean weight } \\
\text { (g) }\end{array}$ & $\begin{array}{c}\text { Mean width } \\
\text { D1 (mm) }\end{array}$ & $\begin{array}{c}\text { Mean depth } \\
\text { D4 (mm) }\end{array}$ & $\begin{array}{c}\text { Mean length } \\
\text { D7 (mm) }\end{array}$ \\
\hline Coffee 1 & C1 & $0.137 \pm 0.022$ & $7.98 \pm 0.47$ & $4.63 \pm 0.24$ & $10.79 \pm 0.99$ \\
Coffee 2 & C2 & $0.147 \pm 0.023$ & $8.43 \pm 0.47$ & $4.79 \pm 0.52$ & $11.13 \pm 2.24$ \\
Coffee 3 & C3 & $0.135 \pm 0.029$ & $8.05 \pm 0.58$ & $4.70 \pm 0.35$ & $10.83 \pm 1.30$ \\
Coffee 4 & I1 & $0.149 \pm 0.026$ & $8.26 \pm 0.62$ & $4.64 \pm 0.28$ & $11.47 \pm 0.84$ \\
Coffee 5 & I2 & $0.146 \pm 0.025$ & $8.34 \pm 0.57$ & $4.79 \pm 0.37$ & $11.90 \pm 1.10$ \\
\hline
\end{tabular}




\section{RESULTS AND DISCUSSION}

During the compression all grains have been crushed. In the Fig. 2 an example of the fracture surface of the grain fragment is shown. One can see high porosity on the fracture surface. An example of the experimental record of the force $\mathrm{F}$ vs. displacement $\mathrm{L}$ is given in the Fig. 3. This record exhibits several peaks of the force. The peak corresponds to the specimen fracture. The first peak is taken as the breaking force of the coffee grain. The grains are crushed into several fragments.

The origin of each fragment starts at the peak of the force. In the given figure the dependence of the work absorbed during grain compression is also shown. The energy is computed as

$$
E=\int F d l .
$$

The obtained parameters exhibited a significant scatter as illustrated in the Fig. 4.

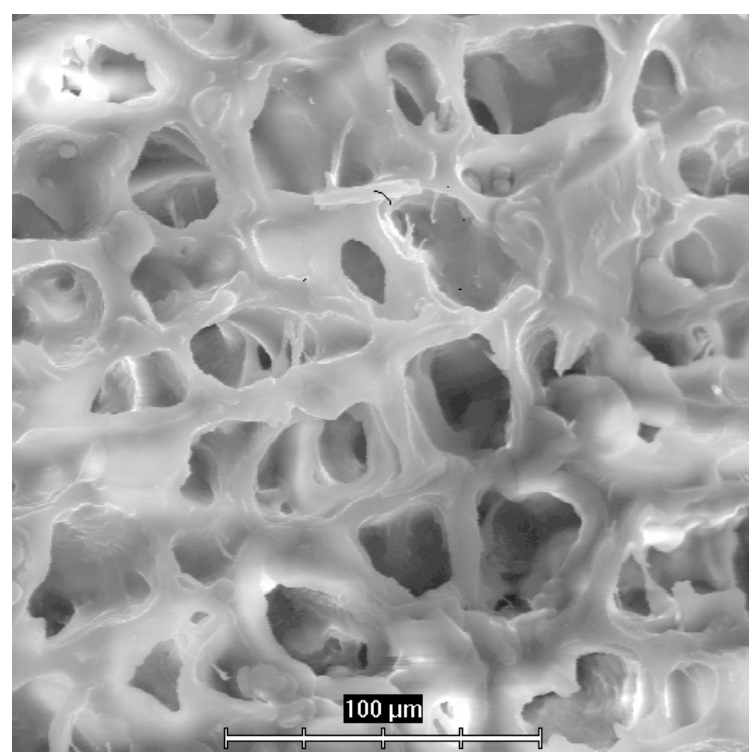

2: Fracture surface of the grain No. 3

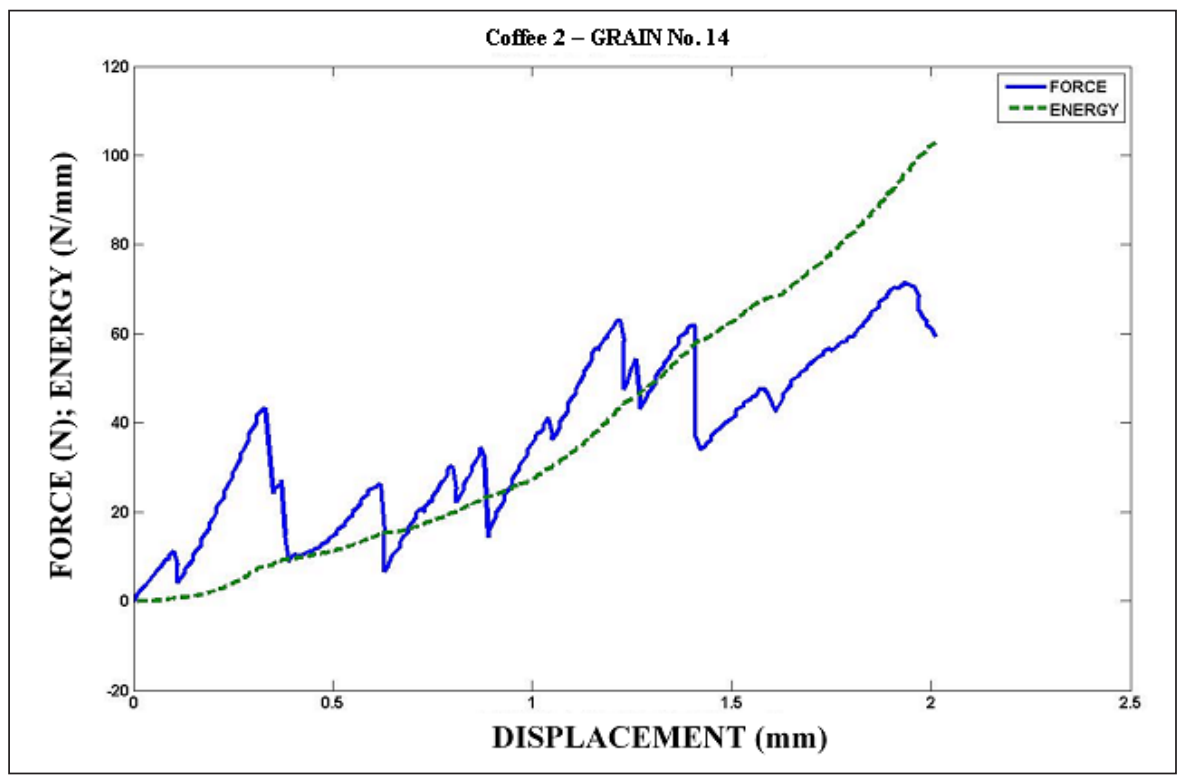

3: Experimental record Force - displacement and energy - displacement

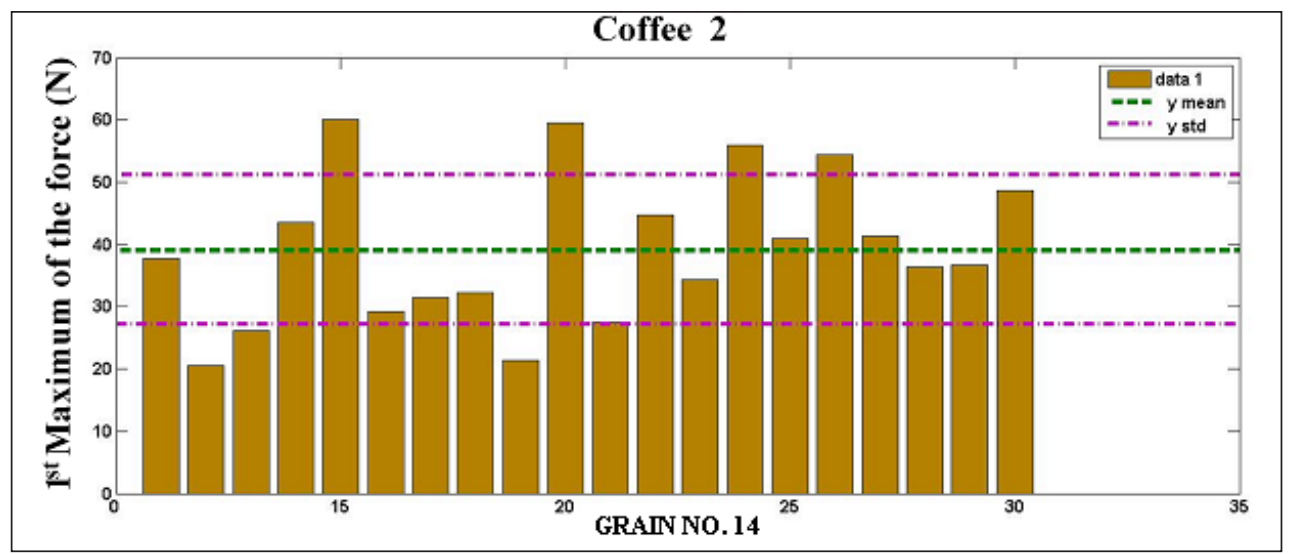

4: Histogram of the breaking force 
The average values of the parameters describing the behaviour of the coffee grains are summarized in the Table II. Results were analysed using analysis of variance according to significant level $(\mathrm{P}<0.01)$.

The detail analysis of the experimental data shows that there is no significant relation between parameters describing the fracture behaviour of the grains and grain geometry. These parameters are also independent on the grain weight.

\section{CONCLUSSIONS}

Compression of the coffee grains leads to their crushing. The fracture force is different for the different kinds of the coffee. The same is fact valid also for the strain at the fracture and for the energy absorbed during the grain crushing.

The obtained results suggest that the fracture parameters obtained at the compression loading are dependent only on the coffee brand and on the roasting conditions. The study of the second of these effects will be subject of the next study.

II: Statistical analysis of the obtained results

\begin{tabular}{lcccc}
\hline \multicolumn{1}{c}{ Coffee code } & Coffee brand & $\begin{array}{c}\text { Breaking force } \\
(\mathbf{N})\end{array}$ & $\begin{array}{c}\text { Strain } \\
(\%)\end{array}$ & $\begin{array}{c}\text { Absorbed energy } \\
(\mathbf{N} / \mathbf{m m})\end{array}$ \\
\hline Coffee 1 & C1 & $51.63 \pm 15.2^{\mathrm{a}}$ & $8.36 \pm 0.62^{\mathrm{a}}$ & $11.93 \pm 3.98^{\mathrm{a}}$ \\
Coffee 2 & C2 & $39.14 \pm 12.00^{\mathrm{bc}}$ & $5.16 \pm 1.15^{\mathrm{d}}$ & $5.99 \pm 2.95^{\mathrm{b}}$ \\
Coffee 3 & C3 & $30.15 \pm 16.23^{\mathrm{bd}}$ & $7.30 \pm 2.69^{\mathrm{ab}}$ & $4.63 \pm 3.69^{\mathrm{b}}$ \\
Coffee 4 & I1 & $49.59 \pm 16.28^{\mathrm{a}}$ & $6.81 \pm 1.72^{\mathrm{bc}}$ & $10.72 \pm 5.60^{\mathrm{a}}$ \\
Coffee 5 & I2 & $36.70 \pm 19.70^{\mathrm{cd}}$ & $6.91 \pm 1.75^{\mathrm{c}}$ & $9.83 \pm 3.22^{\mathrm{c}}$ \\
\hline
\end{tabular}

${ }^{a-d}$ Different letters in the same column indicate that the means are significantly different $(P<0.01)$

\section{SUMMARY}

The deformation and fracture behaviour of the five types of the Arabica coffee grains have been studied. The tested coffee beans have been loaded in compression using of TIRATEST. Cross - head velocity was $20 \mathrm{~mm} / \mathrm{min}$. This velocity is generally accepted as static loading. From the given test the following quantities have been evaluated:

- Breaking force $(\mathrm{N})$ corresponding to force at the major failure event. It was considered as empirical measure of the crushing strength;

- Strain at fracture (\%) corresponding to the deformation at the first breaking point and used as index of the deformability; it was expressed as percentage to keep into account the actual dimensions of the differently heat treated beans;

- Work (J) corresponding to the area under the force - displacement curve until the first breaking event occurred. This parameter has been used as empirical index of toughness. This work represents an absorbed energy during the grain crushing.

The experimental data exhibit large scatter. For the evaluation of some bean property at least 20 coffee beans are needed. The obtained results suggest that there is significant dependence of the parameter mentioned above on the type of the coffee beans. At the same time no dependence on the bean size, weight and shape have been observed. Main source of the difference in the coffee beans properties is thus probably given by the roasting conditions.

\section{SOUHRN}

\section{Drcení zpražených zrn kávy Arabica}

Je sledováno drcení pražených zrn kávy Arabica z pěti různých lokalit. Drcení probíhalo při tlakovém zatěžování kávových zrn pomocí zkušebního zařízení TIRATEST při rychlosti zatěžování $20 \mathrm{~mm} / \mathrm{min}$. Zatěžování při této rychlosti je považováno za statické. Ze získaných experimentálních záznamů byly získány následující údaje:

- Síla, při které dochází k drcení zrna. Tato síla je považována za míru odporu zrna proti drcení.

- Deformace při lomu, která je brána pro posunutí odpovídající výše zmíněné síly. Deformace je brána jako podíl tohoto posunutí vi̊či výšce zrna ve smèru zatěžování.

- Deformační práce, která je považována za míru houževnatosti daného zrna.

Pro získání uvedených vlastností bylo vždy zkoumáno minimálně 20 zrn. Ze statistického vyhodnocení výsledků vyplývá, že mezi kávovými zrny z jednotlivých lokalit existují více či méně významné 
rozdíly. Na druhé straně pak nebyla zjištěna závislost jednotlivých parametrů na hmotnosti, rozměrech a zřejmě i na tvaru kávového zrna.

kávové zrno, rozměry zrna, drcení, lomová síla, lomová deformace, absorbovaná energie

Acknowledgements

The research has been supported by the Grant Agency of the Czech Academy of Sciences under Contract No. IAA201990701.

\section{REFERENCES}

BORGES, A. and PELEG, M., 1997: Effect of water activity on the mechanical properties of selected legumes and nuts. Journal of the Science of Food and Agriculture, 75, 4: 463-471. ISSN 0022-5142.

CLARKE, R. J. and MACRAE, R., 1985: Technology. In: CLARKE, R. J., MACRAE, R. (ed.) Coffee. Volume 2. Barking (UK): Elsevier Applied Science Publishers, 247-270. ISBN 0-85334-368-3.

CLO, G. and VOILLEY, A., 1983: Evaluation of ground coffee particle size for optimum extraction. Lebensmittel-Wissenschaft und-Technologie, 16, 39-42. ISSN 0023-6438.

GHOSH, B. N. and GACANJA, W., 1970: A study of the shape and size of wet parchment coffee beans. Journal of Agricultural Engineering Research, 15, 2: 9199.

GUTIERREZ, C., ORTOLĀ, M.D., CHIRALT, A. and FITO, P., 1993: Analisis for MEB de la porosidad del café tostado. In: Proceedings $15^{\circ}$ Internat. Scientific Colloquium on Coffee, ASIC, Montpellier, France, 661-671.

MASSINI, R., NICOLI, M.C., CASSARÀ, A. and LERICI, C. R., 1990: Study on physical and physicochemical changes of coffee beans during roast- ing. Note 1. Italian Journal of Food Science, 2, 123-130. ISSN 1120-1770.

NEDOMOVÁ, Š., SEVERA, L. and BUCHAR, J., 2009: Influence of hen egg shape on eggshell compressive strength. International agrophysics: a quarterly journal on physics in environmental and food sciences, 23, 249-256. ISSN 0236-8722.

PITTIA, P., DALLA ROSA, M. and LERICI, C. R., 2001: Textural Changes of Coffee Beans as Affected by Roasting Conditions. Lebensmittel-Wissenschaft und-Technologie, 34, 3: 168-175. ISSN 00236438.

ROOS, Y., 1995: Mechanical properties. In: Phase transitions in foods, (ed.) ROOS, Y. London: Academic Press, 247-270. ISBN 978-0-12-595340-5.

SALEH, A. AND GALLAND, D., 1985: Rheological and ultrastructural studies of wheat kernel behaviour under compression as a function of water content. Food Microstructure, 4, 199-211. ISSN 0730-5419.

TRAN, T. L., DEMAN, J. M. and RASPER, V. F., 1981: Measurement of corn kernel hardness. Canadian Institute of Food Science and Technology Journal, 14, 4148. ISSN 0315-5463. 
